\title{
Latvian Queer Kharms? Sex and Power in Rihards Bargais' Gossip
}

\author{
KĀRLIS VĒRDIN̦Š \\ JĀNIS OZOLIN̦Ś
}

\begin{abstract}
In 2012 the Latvian poet Rihards Bargais published a book called Tenkas ('Gossip'), a collection of small absurd narratives, inspired by the Russian writer Daniil Kharms, that describes his fellow writers, well-known Latvian personalities and himself. Many of the pieces have an explicitly sexual character; one of them even resulted in legal action for libel, a situation unique in Latvian contemporary literature. Crossing several boundaries of reality and fiction, private and public, as well as the allowed and the forbidden, Bargais confronts society using sexual imagery in his literary work.
\end{abstract}

Keywords: Latvian literature; gossip; homoeroticism; sexuality; narrative

\section{Queer hooligan $^{1}$}

The Latvian poet Rihards Bargais was born on August 12, 1969 and spent his childhood in Slampe, a village in central Latvia where he attended Zemgale Secondary School. Later he moved to Liepāja to live a bohemian life with an actor of the local theatre, working as a hospital attendant and studying in Liepājas Pedagogical Institute. Afterwards he moved to Riga and enrolled in the Orthodox Theological Seminary. After discontinuing studies there, from 2000 to 2005 he worked as a layout designer for the publishing house "Atēna", an openly pro-gay company. In 2005 for a short while he worked as a TV presenter for the newly-established evening culture programme "100 Grammes of Culture" but was forced to leave it after an ambiguous comment on live TV about the Latvian President Vaira Vike-Freiberga. Since 2006 he has lived in Kekava, a village near Riga, with his partner artist Armins Ozoliṇš, and occasionally works as a layout designer.

Some parts of this article were published as a chapter in Deniss Hanovs, Ilze Jansone, Kārlis Vērdin̦š, eds., Dzimtes konstruēšana II. Rīga: Avens un partneri/LU LFMI, 2014, 117-140. 
VĒRDIN̦Š, OZOLIN̦Š

His first published literary work dates back to 1983: a fairy-tale called "Impatient seeds" that was printed in the children's newspaper "Pionieris". His poetry publications became more frequent in 1992, and during his "Atēna" years the company published his two poetry collections - Mīlvārdini ('Nicknames', 2003) and Labi ('Good', 2005) which gained some recognition for their open homoeroticism and scandalousness. After releasing his debut collection he gave an interview for a tabloid (Pakalns 2003) coming out as gay and announcing that he dedicates his work to Mārtiňš Freimanis, the popular Latvian pop singer, whose sexuality was a subject for tabloids until his premature death in 2011 at the age of 33. Bargais' second collection challenged critics with its vulgar language, sex references and dirty innuendos in short, often rhymed poems inspired by schoolboy folklore and pop culture heroes (Salējs 2007).

After 2005 Bargais switched to writing short anecdotal prose, calling these works Gossip. The first cycle of gossip was published in the literary magazine "Karogs" in 2007 and caused a trial and a scandal as well as elicited extensive discussion in the mass media about the borders between the acceptable and the unacceptable, public and private and reality and art in literary work. The trial was analysed in essays by several Latvian authors and an academic paper by the writer and literary scholar Inga Žolude (see Liepiņš 2008; Jundze 2009; Žolude 2012).

Being openly gay, Bargais has explored subjects new and challenging to readers and writers, subjects uncommon in Latvian literature before Latvia regained national independence. Defining the genre of these Gossip narratives is challenging: are they stories, prose poems or anecdotes? Our paper will explore how the author uses various narrative techniques to confront binary oppositions as well as normative heterosexual discourse. Besides the analysis of Gossip from the viewpoint of narratology and queer theory, we have also quoted Bargais' opinion of his work from an interview with him by the authors of this paper (Vērdiṇš and Ozoliṇš 2014) conducted in January 2014.

\section{Kharms-inspired absurd short prose in contemporary Latvian literature}

As the most significant influence for Gossip Bargais recognizes short stories by he Russian avant-garde writer Daniil Kharms (1905-1942). In Kharm's absurd prose there are many short works dedicated to humorous fictitious episodes from the lives of famous Russian writers, among others Pushkin, Leo Tolstoy, Dostoyevsky and Gogol. Unlike Kharms' famous heroes, Bargais' heroes are 
his contemporaries - young Latvian writers, friends and acquaintances from his childhood and youth as well as Latvian politicians and celebrities.

The reception of Kharm's work in Latvian literature is still an ongoing process. Unknown in his lifetime to Latvian readers, he became a significant inspiration for young writers in the glasnost period of the 1980s as it became possible to read him in Russian. Translations of his works have appeared in Latvian literary press since 1987, he has influenced young prose writers like Aivars Ozolinš, who borrowed images from Kharms' story "Dream” for his own story "Awakening" in his debut collection of short prose "Dukts" in 1991 as well as the poet Žebers (Andris Breže) who turned to absurdist poetic and themes of 'socart' in his collection of poems Tetovèjumi ('Tattoos', 1988).

More systematic use of Kharms' poetics can be observed in contemporary $21^{\text {st }}$-century Latvian prose. Beside Bargais, other followers of Kharm include prose writer Māris Bērziņšs, who has created Gūtenmorgens, the sincere and naive protagonist of his short stories (2007), and writer and publicist Ilmārs Šlāpins, who in his collections of anecdotes (2007 and 2009) recounts absurd stories about the "average Latvian" and about writers and politicians. Šlāpins was also one of Bargais' supporters during the trial.

The first book by Kharms was published in Latvian in 2007 - a small collection of short stories entitled Gadijumi ('Events'). A more comprehensive edition of selected prose was published in 2014. In $2012 \mathrm{Kharm}$ 's novella was adapted for the Latvian National Theatre production of Vecene ('Old Woman'), directed by Vladislavs Nastavševs, utilising horror movie aesthetics.

Works by Latvian authors inspired by Kharms often lack the aggression characteristic of Kharms' writing; absurd scenes and tensions do not escalate into violence or death, they do not take place in perilous situations. Instead they can be characterised as lyrical farce, looking at one's everyday life from unusual viewpoints. As critic Ilva Skulte argued, "violence is rather a peculiar flirting with the position of author-communicator - like emotional violence against the narrative, the protagonists, against oneself and against the reader, but violence softened by irony." (Skulte 2013: 18)

In this polyphony of Kharmsian echoes Bargais has his own distinct voice. It is a viewpoint of a gay man who views himself as slightly feminine, always interested in discussing sexual activities, both his own and others', and in queering every possible situation that provides an opportunity to reflect on pleasure and desire. 
VĒRDIN̦Š, OZOLIN̦Š

\section{Gossip on trial}

Among the short pieces of gossip published in the 2007 August issue of the literary magazine "Karogs" (and republished in the internet news portal "Delfi" soon afterwards) was a piece of short narrative about two persons who were recognisable as two well-known Latvian poets, a man and a woman. One of the author's strategies of emphasising the fictional nature of Gossip was to not capitalise initial letters of personal names, so these poets were referred to as "agita draguna" and "ronalds briedis":

the poets agita draguna and ronalds briedis were sleeping together for a while and were so restless in their sleep that they regularly woke up in the morning lying across each other, forming a perfect Nazi swastika. this tormented the poor souls and was so disturbing that in the end they decided to split up, which they successfully did. (Bargais 2007: 69)

On December 10, 2007, Agita Draguna sent letters to "Karogs" and "Delfi" demanding the publication to be withdrawn, an apology and an arrangement for terms of settlement. When the media did not react, on February 26, 2008 she submitted a claim in the Riga Regional Court against "Karogs", "Delfi" and Rihards Bargais for "withdrawal of news containing infringement of reputation as well as to exact the financial compensation for violating privacy and infringement of reputation. (Satori 2009) She asked for compensation of LVL 200000 (approximately EUR 284 600) from "Karogs" and "Delfi". As she explained, her legal rights had been violated because of false news made public for she had never had a sexual or romantic relationship with Ronalds Briedis, however, they had been good friends for a long time and still were. The press had violated a person's private life, such action is prohibited and was to be punished according to law. As the claimant explained, this publication humiliated and defamed her in the eyes of her children, friends, readers and Latvian society. As she was a member of the Latvian Writers' Union and the readership of her poems supposedly was the same as that of "Karogs", this publication could also threaten her professional life, giving her undesirable publicity and alienating those readers who attach importance to the moral reputation of an author. (Satori 2009)

The trial received much interest from other writers and the media. It raised the question of the nature of the genre of Gossip - how could a "literary anecdote in the style of the absurd" (Satori 2009) be perceived as news that can be measured with the criteria of truth? 
Furthermore, another Draguna's demand was to erase the filthy piece of gossip from all online publications and even internet search engines, including Google - a demand that would be impossible to fulfill. However, in reality during the trial the piece of gossip had been republished in many internet news portals and blogs, and included in various court judgments also available on internet, so the initially marginal text that had remained practically unnoticed for almost a year became frequently talked about, a subject of passionate discussion. On March 23, 2009, the first instance judgment partially satisfied the claim: "Karogs" and "Delfi" were fined LVL 4,000 (almost EUR 6,000) each; Rihards Bargais had to pay the claimant LVL 2,000 (approximately EUR $2,850)$. All defendants appealed the judgment in the Supreme Court. After a two years' wait on March 10, 2011 the Supreme Court upheld the judgment. Defendants appealed the judgment again in the Senate of the Supreme Court. (LETA 2011)

On September 12, 2012 the Senate of the Supreme Court declared that the judgment of the appellant court had to be set aside and the case had to be returned to the appellate instance court (Satori 2012). In the decision it was explained that a literary work does not have to be equated with news and it cannot be treated in the same way. It also stressed the importance of freedom of speech in a democratic society:

These who create, perform, distribute or exhibit their creative work enable the circulation of ideas and opinions in society; this process has an important role in the creation of a democratic society. Thus the duty of the state is to refrain from excessive restrictions of freedom of creative work; [...] the right to express opinions is also guaranteed for ideas and information that can offend, shock or irritate. (Satori 2012)

On December 19, 2013 the Riga Regional Court gave judgment in the appeal case, dismissing the claim. This case created a precedent in Latvian court history: creative freedom was declared more important than an alleged defamation of a person. Taking into account the experience of cases in other countries, the Latvian court defined the legal features of literary work and its crucial difference from news.

This judgment was appealed by the claimant, however. On June 15, 2015 the Civil Department of the Supreme Court refused to propose cassation proceedings, so the judgement of the Civil Chamber of the Supreme Court, dismissing the claim, came into force and the trial finally ended. (Delfi 2015)

During the years of the legal proceedings some publishers refused to publish Bargais' Gossip as a separate book, probably both fearing to undertake a project 
VĒRDIN̦Š, OZOLIN̦Š

which could cause more legal problems if the case ended with the claimant winning and not being aware of the literary quality of these provocative texts. The book edition of Gossip was published at the end of 2012 .

\section{The collection Gossip}

Gossip was published by the cultural internet portal "1/4 Satori", run by the writer and journalist Ilmārs Šlāpins who had followed the case's history and had published articles about the case as well as the full texts of the judgments (Satori 2009 and 2012). The publication was supported by Valsts Kultūrkapitāla fonds (the State Culture Capital Foundation). The "guilty" piece of gossip was not included in the book, other gossip was softened - many persons' names were substituted by random nicknames that made these persons unrecognisable. Much new gossip was added featuring a protagonist called rihards bargais, so instead of ridiculing others the author exposed himself as the main hero of little dirty stories. Reviews of the book were generally positive, critics emphasized Bargais' wit and the charm of his work as well as relief about the positive outcome of the case (Leinerts 2013). The book was even nominated for, although it did not receive, the annual culture prize of the newspaper "Diena".

The book tries to eradicate boundaries: between reality and fiction, between poetry and prose, between different genres of short prose, between the acceptable and the unacceptable, between public and private etc. Furthermore, during the subsequent five years the initial concept of almost uncontrolled wild self-expression evolved into partial self-censorship that takes into consideration possible hostile reactions. If Kharmsian short stories are more or less similar in style and in their way of treating the subject, then Bargais constantly changes his objects of gossip and also the modes of narrative (for example, the same person appears with his/her real name in one story and with a different nickname in others; real persons participate in events they have never been involved in, real episodes from the life of Bargais' friends get obscured to make it impossible to decipher what actually happened). Changing attitudes towards the notions of public/private can be seen in the changing focus of these texts: besides narratives of Bargais' friends and celebrities there are also meditative reflections on the nature of beauty, love and other themes that give nothing to the greedy reader who is interested in gossip. There are texts where the author tries to create the feeling of presence and reality and, on the other hand, introspective visions and unreal fantasies that are not meant to be believable. Probably the real process of gossiping will start after reading the 
book: confused readers will try to figure out which stories are true and who is hiding behind the nicknames.

\section{The problematic of genre: communicative or literary practice?}

In the context of social psychology, gossiping can be viewed as a communicative practice. It surely has its literary potential of which Rihards Bargais is well aware. Gossip as an element of literary narrative had been used already in $18^{\text {th }}$ and $19^{\text {th }}$ century novels (well-known examples are works by Lawrence Sterne and Jane Austen), it has been associated with the tradition of oral narratives and the transfer of certain knowledge, however, this knowledge is rather fragmented and ambiguous, mediated by interpretation that does not make an attempt to clarify the facts and to examine verity. Here the narrative quality of gossip can be found: how this fragmented knowledge can be transformed into a story.

Another important fact is that gossip takes place among mutual acquaintances, not necessarily friends, and their intimacy can also be just a game that involves the narrator and his/her listener or a group of listeners. Complicated narrative structures are replaced by attention to detail that underlies the gossip. The abundance of details helps the story move on, makes ir gripping, even exciting. There are some prose genres, for example the novel, where detailed descriptions form commentaries which, on the other hand, slow down the pace of events, thus sometimes annoying the reader (like Sterne's Tristram Shandy). At the same time, attention to detail has been useful for the development of the genre, especially if it contains erotic or even pornographic elements (de Sade and the subsequent tradition of pornographic literature).

Returning to the question of the narrative qualities of gossip, the way the narrator interprets his/her fragmented knowledge is significant (for example, repeating something said by somebody else), thereby creating a literary text. There are several categories of gossip and they cannot be treated equally: among them are the reliability of knowledge and the transition of a communicative act into a literary text. The discourse of sexuality heightens the sensitivity of society's perception of this literary text, because it encompasses the practices of pleasure, dietetics, economy, erotica, etc. This is reflected in the court case's narrative about defamation, which became irreversibly intertwined with the texts themselves.

In the case of Bargais the question of genre is especially important because he transgresses the boundaries of genres. Gossip still features basic narrative qualities (with an event or sequence of events that is temporally and causally 
VĒRDIN̦Š, OZOLIN̦Š

bound), the amount of text is small. Under the guise of gossip one can find a miniature, a parable, an epiphany or an anecdote as well as a prose poem or even a rhymed prose poem.

As Barthes has said, "A text on pleasure cannot be anything but short (as we say: is that all? It's a bit short)" (Barthes 1975: 18); and the function of gossip as a text also confirms that they are short texts that stimulate the imagination and are meant to be reread. Herein lies the perversity of gossip in its written form: oral gossip can be heard once and then retold to another person but gossip that has been written down becomes disseminated and can be read over and over again. The object of gossip recognises with Socratic helplessness that the written word stands against him/her even though it is just a joke. Though the author of Gossip desired to enjoy being uncontrolled and unbridled, the concrete legal proceedings were a considerable attempt to curtail that pleasure. However, the legal process took a different turn - it was now a question of the freedom of the written word.

The pleasure of the text: the author's pleasure and the reader's pleasure

Understanding of the text is dependent on the reader's interpretation. Gossip includes the presumption of pleasure which we are aware of in relation to the author (even if he hides himself behind the construction of the implicit author). However, the author cannot be sure of the pleasure of the reader. Choosing to contribute to the genre of gossip, the author foresees the collaboration of the reader despite the reader's reaction of surprise, curiosity, disgust, shock etc.

Still, the psychological reaction does not indicate the different types of reader, being classified by Barthes in The Pleasure of the Text: the fetishist, the obsessive, the paranoiac and the hysteric. (Barthes 1975: 63) In the case of Bargais, two types of readers are important: his ideal reader is the fetishist like himself, "matched with the divided-up text, the singling out of quotations, formulae, turns of phrase, with the pleasure of the word", (ibid.) however, publishing gossip as literary text Bargais met the dangerous type of reader the hysteric, "the one who takes the text for ready money, who joins in the bottomless, truthless comedy of language, who is no longer the subject of any critical scrutiny and throws himself across the text (which is quite different from projecting himself into it)" (ibid.).

Bargais is aware of the negative connotations of gossip but for him it is an effective way both for criticism and for disarming the reader. It is a holy trinity that has been consciously constructed: amorality, triviality and frivolity. 
Mediocre dreams and fantasies also have a right to exist! These manifestations go together well with idle talk and laziness which characterise both Gossip as well as the lifestyle of the author in the period of writing and editing this collection. (Bargais 2014) A reader, being an interested subject, surrenders to these rules of the game and joins the process listening to the gossiping narrator who recounts different events involving well-known people and others, mainly writers, politicians, gays, celebrities, colleagues - anybody who has had a relationship to Bargais or has aroused his interest by doing something amusing or irritating.

Gossiping can also be "a momentary desquamation of the writer's hackles" (Barthes 1975: 30) in a moment when he himself becomes an object of gossip (or his projection - the implied author). At this moment the author turns his weapon against himself, however, it would be hasty to call it mere self-irony. The implied author is of two natures - criticising himself he gets pleasure through his daring to show off. This is a triple pleasure - imagined pleasure has been written down with pleasure, hoping that the reader also will experience pleasure.

The effectiveness of gossip is based on the intentions of the author - ideology and subject-matter - equal importance has also been given to representation. Impudence without boundaries and total provocation is the ideal of gossip. However, the printed collection of gossip does not reflect this ideal - Bargais becomes intimidated by the legal process, not because of the pressure from society but just because of the lack of humour of the claimant (the hysterical type!). Restrictions materialise into a form of self-censorship: real names of people have been replaced by various metaphorical nicknames and the reader is now invited to decipher them. However, the result is contradictory - the curious reader gets only partial satisfaction and mysterious nicknames that mask well-known people do not work. Can the undecipherable text still be called gossip? Or has it become superficial pomp?

At the same time the ideological framework of Gossip includes the role of the outcast, marginality, disappointment and otherness. As can also be seen in the gay-themed documentary "Homo.lv" in which Bargais and his partner participate, his negative attitude towards Riga Gay Pride shows his wish to stand apart, to not have radical viewpoints on the role of otherness which are so prominent in his texts. Bargais does not hide his queer identity, but at the same time he is not capable of offering new perspectives (on the other hand, Gossip is just literary fiction and one cannot ask more from it because it lacks a social function).

Still the legal process inspired society to re-evaluate the understanding of the literary text and its taboos: gossip is most of all "a reinstating of pleasure 
VĒRDIN̦Š, OZOLIN̦Š

within reality" (Foucault 1978: 5), to be precise, in reality of text. It was received as a transgression of law, so the mechanisms of power were put into motion and the author was accused of violating the law. Later the prohibitions were lifted, so reality was separated from fiction. This list of conditions, borrowed from Foucault's History of Sexuality, still has not lost its meaning if we think about repressive systems that inveigh against sexuality, "For the least glimmer of truth is conditioned by politics" (ibid.). Even today.

\section{The Body in Gossip}

Deeply influenced by pop culture, Bargais frequently pays attention to bodies of various people. In his text "On Joe Dallesandro" the perfect body of the bisexual film actor becomes an embodiment of truth: "Beautiful people know truth with their appearance" (Bargais 2012: 74), and the author, willing to acquire this truth, dreams of fucking the beautiful people. In another text, Bargais recalls a scene in his youth when he goes to Liepāja's public swimming pool and in the showers meets a well-known Latvian politician, deemed an oligarch (Ainārs Šlesers), helps him wash his back and becomes sexually aroused by the "big, athletic and naked" body of the future homophobic politician (Bargais 2012: 75). Šlesers, now known for his aggressive populism, has been made an object of queer desire, shown naked at a time he had not yet acquired wealth and power.

Some texts also celebrate the phallus. The book opens with a piece of gossip, dedicated to the literary critic who has an "disproportionately long rihards" (i.e. penis) that strokes the seat of his chair while the critic writes his striking reviews (Bargais 2012: 11). Another piece of Gossip recommends a well-known Latvian TV soap opera director to include a footage of naked phalluses if she wants to make her series immortal - the presence of a phallus enables every cultural production achieve immortality (Bargais 2012: 138). The importance of seeing a phallus reappears in a piece of Gossip about Bargais' primary school years when he and his classmate Beitāns hid in the school's shed to look at pictures of naked female breasts in Soviet health magazines. Their attention is drawn to the math teacher who urinates by the shed, unknowingly showing off his "big and red" penis, exciting the boys. (Bargais 2012: 152-153)

The phallus is also present in gossip about sexual activity. In a text, written in the first person, that takes place on a gay beach, the narrator performs oral sex on a stranger who, despite his beautiful body, turns out to be an egoist, unable to give and receive pleasure. (Bargais 2012: 156-157) Another piece of Gossip, written in the third person, about a gay sado-masochistic couple, 
depicts a masochist who has been ordered to sit immobile with the sadist's cock in his mouth and look at him while the latter sits comfortably on a sofa for hours enjoying various TV shows (Bargais 2012: 73). For Bargais the phallus becomes an object of worship that has to be acquired but for some reason this desire always remains unfulfilled.

Yet more challenging is the presence of the anus. This part of the body has been theorised in works by Guy Hocquenghem stressing the difference between the public phallus and the private anus; so some motives in Gossip recall his ideas:

We only see our anus in the mirror of narcissism, face to face, or rather back to front, with our own clean, private little person. The anus only exists as something which is socially elevated and individually debased; it is torn between faeces and poetry, between the shameful little secret and the sublimated. (Hocquenghem 1993: 100)

As Jonathan Allan has recently observed, the anus is "a remarkably complex organ, sign, and symbol that appears repeatedly in literature and culture"; contemporary culture is fascinated by it. However, the anus still remains "covered, hidden away, a site of humiliation and disgust". (Allan 2016: 2-3) This is exactly the kind of image that Bargais needs for his soft queer provocations.

In a text "On intelligence building", written in the first person, Bargais describes his supposed everyday routine - the exercise of anal muscles. He goes into detail explaining the set of exercises that helps him train his penis, testicles, anus and prostate. He makes a statement that this kind of "intelligence building" can replace university studies. (Bargais 2012: 108-109) In this text the anus remains in the realm of privacy and narcissism, however, Bargais crosses the boundary in another short piece of Gossip about himself:

for sexual reasons the poet rihards bargais loved to insert into his anus a smooth, cylindrical steel lighter, which was afterwards carefully washed under the tap and proudly put on the table for his friends, who had come to a party, to light their cigarettes with. (Bargais 2012: 114)

Here the anus gets involved in actions that blur the border between the private and the public. Being the first Latvian author who has dared to write about his anus (no matter if the stories are true or false) Bargais dedicates both of these texts to his own person, real or imagined. 
VĒRDIN̦Š, OZOLIN̦Š

\section{Conclusion}

As these examples show, Bargais looks both at society and himself with a queer gaze. Although he might have reason to consider himself marginalised both in terms of literature and social position - a gay not striving for power, content to assume the role of an ironic commentator - he does achieve power by freely recounting his observations and fantasies, using names of real people and placing them in absurd situations or undressing them, thus subjecting them to judgement.

Bargais' gossip, while less cruel and surreal than works by Daniil Kharms, still has the transgressive power to question such issues as power, privacy, gender, sexuality, body and fame, at the same time avoiding serious answers. A similar concept can be observed in his new literary project - autobiographical fragments that he frequently publishes on Facebook.

\section{Kārlis Vērdiṇš}

karlis.verdins@lulfmi.lv

LU Literatūras, folkloras un mākslas institūts

Mūkusalas iela 3

LV-1423 Riga

LATVIJA / LATVIA

\section{Jānis Ozoliņš}

janis.ozolins@lulfmi.lv

LU Literatūras, folkloras un mākslas institūts

Mūkusalas iela 3

LV-1423 Riga

LATVIJA / LATVIA

\section{Bibliography}

Allan, J. A. 2016. Reading from Behind: A Cultural Analysis of the Anus. London: Zed Books.

Bargais, R. 2007. Tenkas. - Karogs, 8, 68-74.

Bargais, R. 2012. Tenkas. Rīga: Ascendum.

Barthes, R. 1975. The Pleasure of the Text. Translated by Richard Miller. New York: Hill and Wang.

Delfi. 2015. Dzejniekam Bargajam un medijiem nebūs jāmaksā Dragunai par “tenkošanu”. Delfi, June 16. - http://www.delfi.lv/news/national/politics/ dzejniekam-bargajam-un-medijiem-nebus-jamaksa-dragunai-par-tenkosanu.d? $\mathrm{id}=46114193$ (01.09.2015). 
Latvian Queer Kharms? Sex and Power in Rihards Bargais' Gossip

Fritsch, E. 2005. Gossip. - Herman, D., Jahn, M. and Ryan, M.-L., ed. Routledge Encyclopedia of Narrative Theory. London and New York: Routledge, 207-208.

Harmss, D. 2007. Gadijumi. Translated by Vasīlijs Voronovs. Rìga: Neputns.

Harmss, D. 2014. Prozas izlase. Translated by Haralds Matulis. Rīga: Mansards.

Hocquenghem, G. 1993. Homosexual Desire. Translated by Daniella Dangoor. Durham and London: Duke University Press.

Jundze, A. 2009. Prāva, kas apdraud latviešu literatūras pastāvēšanu. - Neatkarīgā Rìta Avize, 24.03, 14.

Foucault, M. 1978. The History of Sexuality. Volume 1. Translated by Robert Hurley. New York: Pantheon Books.

Leinerts, D. 2013. Tenka, ko ar roku ierakstīt aiz atrunas. - Latvju Teksti, 1, 42-43.

LETA. 2011. Par dzejnieces goda un cieñas aizskārumu būs jāmaksā Ls 10 000, Tvnet, 10 March. - http://www.tvnet.lv/zinas/latvija/369225-par_dzejnieces_goda_un_ cienas_aizskarumu_bus_jamaksa_1s_10_000(01.08.2014).

Liepiňš, I. 2008. Kā strīds starp Agitu Dragunu un Rihardu Bargo parāda latviešu literatūras vājumu. - Karogs, 4, 205-206.

Pakalns, J. 2003. Dzejnieks - gejs savus dzejoḷus velta Mārtin̦am Freimanim. - Privātā Dzive, 29.04, 30-31.

Rigas apgabaltiesa. 2013. - http://at.gov.lv/en/court-information/the-docket/?year= $2013 \&$ month $=12 \&$ day $=19(01.08 .2014)$.

Salējs, M. 2007. Dzejas ainas ieskicējums. - Silova, L., ed. Versija par...: Latviešu literatūra 2000-2006. Rīga: Valters un Rapa, 11-57.

Satori. 2009. Tiesas spriedums A. Dragunas lietā (pilns teksts). Satori, 24.03. - http:// www.satori.lv/raksts/2700 (01.08.2014).

Satori. 2012. Augstākās tiesas senāts: 12. septembra spriedums Riharda Bargā "Tenku" lietā. Satori, 20.11. - http://satori.lv/raksts/5062/Augstakas_tiesas_Senats/12_ septembra_spriedums_Riharda_Barga_Tenku_lieta (01.08.2014).

Skulte, I. 2013. Tanku un tenku ieroči. - Latvju Teksti, 4, 17-20.

Vērdiņš, K., Ozoliņš, J. 2014. Interview with Rihards Bargais on 19 January.

Žolude I. 2012. Balts-melns - dzeja un likums: realitāte un fikcija Riharda Bargā grēksūdzes tipa "Tenkās”. - Stašulāne A., ed. Kultūras studijas: krāsa kultūrā. Daugavpils: Saule, 339-347. 